\title{
PERAN, HAK, KEWAJIBAN SERTA PROFESIONALISME SEORANG GURU DI INDONESIA
}

\author{
Nellyana Azizah
}

Email: 2010111220014@mhs.ulm.ac.id

Program Studi Pendidikan Sejarah Fakultas Keguruan dan Ilmu Pendidikan

Universitas Lambung Mangkurat

Banjarmasin

\begin{abstract}
Abstrak
Profesi secara etimologi berasal dari kata profession (Inggris) yang berasal dari bahasa latin profesus yang berarti "mampu atau ahli dalam suatu bentuk pekerjaan". Profesi juga dapat diartikan sebagai suatu pekerjaan atau jabatan yang menuntut keahlian, yang didapat melalui Pendidikan dan Latihan tertentu, menurut persyaratan khusus memiliki tanggung jawab dan kode etik tertentu. Suatu profesi memerlukan kemampuan dan keahlian khusus dalam melaksanakan profesinya. Penegasan guru sebagai jabatan profesi guru tertuang di dalam pasal 1 Undang - undang No 14 tahun 2005 tentang guru dan dosen, yakni sebagai berikut, guru adalah pendidik professional dengan tugas utaman mendidik, mengajar, membimbing, mengarahkan, melatih, menilai dan mengevaluasi peserta didik pada Pendidikan anak usia dini jalur Pendidikan formal, Pendidikan dasar, dan Pendidikan menengah. Jabatan guru dilatarbelakangi oleh adanya Lembaga Pendidikan yang menghasilkan calon guru untuk menghasilkan guru yang professional. Dan sebab itu lah kenapa adanya profesi guru.
\end{abstract}

\section{PENDAHULUAN}

Menurut Kamus Besar Bahasa Indonesia, Profesi adalah bidang pekerjaan yang dilandasai Pendidikan keahlian (keterampilan, kejujuran, dan sebagainya). Dapat dipertegas bahwa profesi merupakan pekerjaan yang harus dikerjakan dengan bermodal keahlian,keterampilan, dan spesialisasi tertentu. (Suteja, 2019: 48)

Profesi secara etimologi berasal dari kata profession (Inggris) yang berasal dari bahasa latin profesus yang berarti "mampu atau ahli dalam suatu bentuk pekerjaan". Profesi juga dapat diartikan sebagai suatu pekerjaan atau jabatan yang menuntut keahlian, yang didapat melalui Pendidikan dan Latihan tertentu, menurut persyaratan khusus memiliki tanggung jawab dan kode etik tertentu. Suatu profesi memerlukan kemampuan dan keahlian khusus dalam melaksanakan profesinya. (Susanto, 2020:97)

Jabatan guru dilatarbelakangi oleh adanya Lembaga Pendidikan yang menghasilkan calon guru untuk menghasilkan guru yang professional. Dan sebab itu lah kenapa adanya profesi guru. (Hasanah, 2012:03) 
Guru merupakan suatu profesi, yang berarti suatu jabatan yang memerlukan keahlian khusus sebagai guru dan tidak dapat dilakukan oleh sembarang orang di luar bidang Pendidikan. (Susanto, 2020:97).

\section{PERAN GURU SEBAGAI SEBUAH PROFESI}

Penegasan guru sebagai jabatan profesi guru tertuang di dalam pasal 1 Undang undang No 14 tahun 2005 tentang guru dan dosen, yakni sebagai berikut, guru adalah pendidik professional dengan tugas utaman mendidik, mengajar, membimbing, mengarahkan, melatih, menilai dan mengevaluasi peserta didik pada Pendidikan anak usia dini jalur Pendidikan formal, Pendidikan dasar, dan Pendidikan menengah. Guru adakag sumber daya manusia yang sangat penting dalam pengelolaan Pendidikan yang berperan dalam meniapkan generasi masa depan. Dalam undang- undang tersebut dijelaskan kedudukan guru sebagai tenaga professional dimaksudkan untuk melaksanakan system Pendidikan Nasional dan mewujudkan tujusn Pendidikan Nasional, yaitu berkembangnya potensi peserta didik agar menjadi manusia yang beriman dan bertakwa kepada Tuhan Yang Maha Esa, berakhlak mulia, sehat berilmu, kreatif, mandiri, serta menjadi warga negara yang demokratis dan bertanggung jawab. (Alinurdin, 2019:03)

Berdasarkan Undang - Undang RI No.14 tahun 2005 tentng guru dan dosen pasal 1, yang sudah dijelaskan diatas tadi tentang peran, hak dan kewajiban seorang guru. Pendidik atau guru sebagai sebuah profesi di bidang Pendidikan yang di geluti, Hak - hak guru merupakan apa saja yang didapatkan oleh seseorang yang memiliki profesi guru, dan kewajiban guru adalah apa saja yang harus dilaksanakan seorang guru dalam menjalankan profesinya.Guru dapat diartikan sebagai orang yang tugasnya terkait dengan upaya mencerdaskan kehidupan bangsa dalam semua aspeknya, baik spiritual, emosisonal,intelektual, fisikal maupun aspek lainnya. Menurut Djarmah Jabatan guru memiliki banyak tugas, baik yang terikat oleh dinas maupun di luar dinas dalam bentuk pengabdian. Tugas guru tidak hanya sebagai suatu profesi, tetapi juga sebagai suatu tugas kemanusiaan dan kemasyarakatan. Tugas guru sebagai suatu profesi menuntut kepada guru untuk mengembangkan profesionalitas diri sesuai perkembangan ilmu pengetahuan dan teknologi. Mendidik, mengajar, dan melatih anak didik adalah tugas guru sebagai pendidik berarti meneruskan dan mengembangkan nilai- nilai hidp kepada peserta didik. Tugas guru sebagai pelatih berarti mengembangkan keterampilan dan menerapkannya dalam kehidupan demi masa depan peserta didik. (Susanto, 2020: 97)

\section{GURU INDONESIA DAN TANTANGAN PROFESIONALISME}

Profesional sering diartikan sebagai suatu keterampilan teknis yang dimiliki seseorang. Untuk dapat menjalankan suatu pekerjaan secara professional atau memiliki profesionalisme, sudah barang tentu diperlukan seperangkat pengetahuan, sikap, dan keterampilan tertentu. Ada beberapa alasan yang rasional sehingga tugas mengajar tersebut 
sebagai profesi, yaitu: (1) bidang tugas guru memerlukan perencanaan yang matang, pelaksanaan yang mantap dan pengendalianyang baik, (2) bidang pekerjaan mengajar memerlukan dukungan ilmu teorotis Pendidikan dan mengajar, (3) bidang Pendidikan ini memerlukan waktu lama dalam masa Pendidikan dan Latihan, sejak Pendidikan dasar sampai Pendidikan tenaga keguruan. Lebih lanjut dijelaskan bahwa yang dikatakan guru sebagai guru professional memiliki karakteristik seperti: memiliki ilmu pengetahuan yang luas dalam bidang yang dikerjakan, memiliki kemampuan dan keterampilan dalam melaksanakan pekerjaannya sesuai bidangnya, memiliki karakter atau kepribadian yang membuatnya dihargai, dibanggakan dan diterima kliennya, mampu mengembangkan anak didik berkualitas dalam kegaiatan pembelajaran yang dilakukan.

Berdasarkan penjelasan diatas dapat dipahami bahwa salah satu factor yang mendukung upaya pembentukan peserta didik yang berkualitas dalam proses pelaksanaan kegiatan Pendidikan di sekolah adalah keberadaan guru professional, dimana yang dikatakan guru professional adalah guru yang memiliki kemampuan meliputi, meguasai pengetahuan pada bidangnya, memiliki sikap yang baik dan dapat diterima dimana saja, serta mampu meningkatkan kualitas peserta didiknya yaitu mereka dan mampu mengimplementasikan dalam kehidupan. (Hanafi, 2019:02)

\section{SIMPULAN}

Profesi adalah bidang pekerjaan yang dilandasai Pendidikan keahlian (keterampilan, kejujuran, dan sebagainya). Dapat dipertegas bahwa profesi merupakan pekerjaan yang harus dikerjakan dengan bermodal keahlian,keterampilan, dan spesialisasi tertentu. Guru merupakan suatu profesi, yang berarti suatu jabatan yang memerlukan keahlian khusus sebagai guru dan tidak dapat dilakukan oleh sembarang orang di luar bidang Pendidikan.

Penegasan guru sebagai jabatan profesi guru tertuang di dalam pasal 1 Undang undang No 14 tahun 2005 tentang guru dan dosen, yakni sebagai berikut, guru adalah pendidik professional dengan tugas utaman mendidik, mengajar, membimbing, mengarahkan, melatih, menilai dan mengevaluasi peserta didik pada Pendidikan anak usia dini jalur Pendidikan formal, Pendidikan dasar, dan Pendidikan menengah.

Profesional sering diartikan sebagai suatu keterampilan teknis yang dimiliki seseorang. Untuk dapat menjalankan suatu pekerjaan secara professional atau memiliki profesionalisme, sudah barang tentu diperlukan seperangkat pengetahuan, sikap, dan keterampilan tertentu. Ada beberapa alasan yang rasional sehingga tugas mengajar tersebut sebagai profesi, yaitu: (1) bidang tugas guru memerlukan perencanaan yang matang, pelaksanaan yang mantap dan pengendalianyang baik, (2) bidang pekerjaan mengajar memerlukan dukungan ilmu teorotis Pendidikan dan mengajar, (3) bidang Pendidikan ini memerlukan waktu lama dalam masa Pendidikan dan Latihan, sejak Pendidikan dasar sampai Pendidikan tenaga keguruan. 


\section{REFERENSI}

Efendi, I., Prawitasari, M., \& Susanto, H. (2021). Implementasi Penilaian Pembelajaran Pada Kurikulum 2013 Mata Pelajaran Sejarah. Prabayaksa: Journal of History Education, 1(1), 21-25.

Susanto, H. (2020). Profesi Keguruan. Banjarmasin: FKIP Universitas Lambung Mangkurat.

Susanto, H., \& Akmal, H. (2018). Efektivitas Penggunaan Aplikasi Pembelajaran Berbasis Mobile Smartphone Sebagai Media Pengenalan Sejarah Lokal Masa Revolusi Fisik Di Kalimantan Selatan Pada Siswa Sekolah Menengah Atas. HISTORIA: Jurnal Program Studi Pendidikan Sejarah, 6(2), 197-206.

Susanto, H., Irmawati, I., Akmal, H., \& Abbas, E. W. (2021). Media Film Dokumenter Masuknya Islam Ke Nusantara dan Pengaruhnya Terhadap Keterampilan Berpikir Kritis Siswa. HISTORIA: Jurnal Program Studi Pendidikan Sejarah, 9(1).

Syaharuddin, S., \& Susanto, H. (2019). Sejarah Pendidikan Indonesia (Era Pra Kolonialisme Nusantara sampai Reformasi). Banjarmasin: FKIP Universitas Lambung Mangkurat.

Hanafi, H., Adu, L., \& Muzakkir. (2019). Profesionalisme guru dalam pengelolaan kegiatan pembelajaran di sekolah. Yogyakarta. Deepublish (grup Penerbit CV Budi Utama).

Suteja, J. (2019). Etika Profesi Keguruan. Yogyakarta. Deepublish (grup Penerbit CV Budi Utama).

Alinurdin, Balianto, P., Nurzaman. Profesi Keguruan. Tanggerang Selatan. Universitas Pamulang S1 pendidikan PKN. UNPAM PRESS 